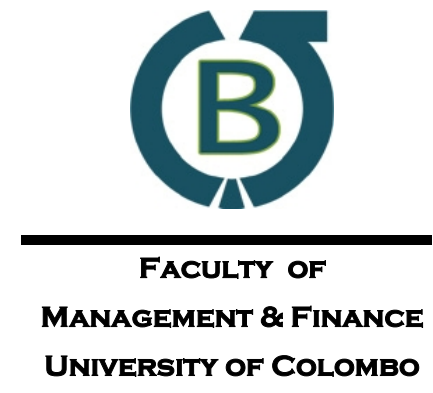

UNIVERSITY OF COLOMBO
Vol. 07, No. 01, June, 2016
Colombo

Business

Journal

International Journal

of Theory \& Practice

\title{
Econometric Analysis of Trade Openness and Economic Growth for Developing Countries
}

\author{
Muhammad Tahir ${ }^{a 1}$, Mohammad Saeed Lodhi ${ }^{\text {b }}$ \\ ${ }^{a, b}$ Department of Management Sciences, COMSATS Institute of Information Technology, Pakistan
}

\begin{abstract}
This paper has examined the relationship between trade openness and economic growth in the developing countries in order to have a better understanding of the trade-growth relationship. Empirical analyses are carried out through panel fixed effects estimation procedure, and data are utilized for two samples of the developing countries for the period 1990-2009. The endogeneity issue of trade openness is handled through instrumental variable. Our main finding is that the relationship between trade openness and economic growth is positive and statistically significant. The impact of domestic investment, labour force, education, and democracy on economic growth is also positive and statistically significant. The results also show that uncertain policies such as frequent fluctuations in prices are detrimental to long-run economic growth. It recommended that the developing countries should liberalize international trade, ensure macroeconomic stability, and pay favourable attention to other determinants of economic growth in order to grow faster in the long-run.
\end{abstract}

Keywords: $\quad$ Trade Openness, Growth, Fixed Effects Models, Endogeneity, Instrumental Variables

\section{Introduction}

The impact of trade openness on economic growth has attracted much attention in literature during the last couple of decades. International trade openness is considered a key determinant of economic growth in recent times. International organizations such as World Trade Organization (WTO) and International Monetary Fund (IMF) are constantly advising the developing countries to move towards more liberal regime. The spectacular growth experience of the Tiger economies of Asia (Singapore, South Korea, Taiwan, and Hong Kong) over the years, and the recent growth experience of some of the developing countries such as India and China, after moving towards liberal regime, have forced policy makers especially in the developing world to implement outward-oriented policies. Such policies are expected to influence the growth process of the developing countries positively.

While there is a very rich empirical literature on the relationship between trade openness and economic growth, the positiveness and the negativity of the relationship are still debatable, owing to

${ }^{1}$ Corresponding Author: tahirm@ciit.net.pk 
mixed empirical evidence. Some studies such as Dollar (1992), Sachs and Warner (1995) and Edwards (1998) have provided sound evidence in favour of the positive relationship between trade openness and economic growth. On the other hand, researchers such as Rodrik and Rodriguez (2000) and Rodriguez (2007) are sceptical of the positive trade-growth relationship. Their criticism mainly applies to the methodologies and measures of trade openness used.

This paper aims at contributing to the empirical evidence regarding the trade - growth relationship in the developing countries in various ways. To do this, first, the relationship between trade openness and economic growth for a sample of 67 developing countries, which consists of 14 low-income, 27 lower-middle-income and 26 upper-middle- income economies is tested. Second, upper-middle economies are excluded from the initial sample to enable us focus on lower - middle - income and low - income economies. The rationale behind doing this is to examine the role of trade openness for economic growth in the lower-middle-income and low-income economies. The developing countries need policy lessons regarding international trade in order to implement and execute appropriate policies to speed up growth process. It has been observed, over the years, that the developing countries are reluctant to open their markets to the international trade because of persistent confusion created by mixed empirical research. This study provides comprehensive policy lessons for the developing countries regarding international trade policy.

In this paper, we have briefly reviewed both theoretical and empirical literature on the relationship between trade openness and economic growth, to provide a prelude for subsequent discussions in section 2. Next, we present a summary of statistics on trade openness and per capita GDP. Further, specification of model, sample and data, endogeneity issue and estimating methodology are dealt with. Discussion of the main findings is included in the penultimate section. The paper ends with conclusions and recommendations.

\section{Literature Review}

\subsection{Theoretical Literature}

International trade openness and its relationship with economic growth is a well-researched topic in trade-growth literature. Theories of international trade strongly support the hypothesis that increased openness to international trade can influence economic growth positively. According to the absolute advantage theory of international trade, international trade gives access to extended international markets and improves productivity through division of labour (Smith, 1776). Small size of the domestic market acts as a hurdle to economic growth particularly in the developing countries. Thirlwall (2000) argues that the major dynamic benefit of international trade is that domestic producers get access to widened markets. The comparative advantage theory believes that international trade is beneficial and brings production gains and consumption gains to trading partners (Ricardo, 1817). In the same way, Carbaugh (2005) has argued that, in the framework of new trade theory, economies with similar resource endowments and negligible comparative advantage may benefit from the international trade because of massive economies of scale.

Additionally, theoretical literature has indicated that trade openness has the capacity to accelerate and sustain long-run economic growth by improving productivity, increasing competitive pressure among the domestic producers and channels of domestic investment (Dobre, 2008). Grossman and Helpman (1994) have argued that open economies can access larger technical knowledge base than 
closed economies. Further, they have argued that in the process of technological dissemination, trade can play a vital role.

In theoretical literature, Fiestas (2005) has documented that liberalization of international trade stimulates income and long-run economic growth. It is worth noting that theoretical literature on trade openness has documented that trade openness improves economic growth. According to Lopez (2005) and Lin (2000), this improvement in economic growth occurs through enhancing the allocative efficiency and channelling of foreign direct investment. In recent times however, some controversies have been raised among researchers on trade-growth relationship in the framework of trade theories. In a recent paper, Bajona, Gibson, Kehoe, and Ruhl (2010) have analysed various static and dynamic models of international trade; they conclude trade models only predict that trade openness can improve social welfare, but not necessarily economic growth. Further, theoretical literature does not provide a decisive answer to the trade-growth relationship (Ulasan, 2012).

\subsection{Empirical Literature}

Extensive studies have been conducted on the relationship between trade openness and economic growth during the last couple of decades. Empirical evidence regarding the trade-growth relationship in the context of developing countries is mixed. Some researchers such as Dollar (1992), Sachs and Warner (1995), and Frankel and Romer (1999) are very much convinced about the positive relationship between trade openness and economic growth. Rodrik and Rodriguez (2000), however, have cast doubts on the positive relationship between trade openness and economic growth by highlighting problems related to applied methodologies and the way trade openness is measured. For instance, Rodriguez (2007) has focused on recent empirical studies (Dollar \& Kraay, 2002; Warner, 2003; Wacziarg \& Welch, 2003) and concluded that standard measures of trade policy are not related to economic growth.

On the other hand, Bhagwati and Srinivasan (2001) have analysed the criticism Rodrik and Rodriguez (2000) have made about the positive relationship between trade openness and economic growth and commented that the criticism is unpersuasive. Warner (2003) has commented that the crucial evidence is ignored and indeed there was a negative relationship between trade restrictions and economic growth. In a recent study, Panagariya (2004), has also paid attention to the criticism made by Rodrik and Rodriguez (2000) about the positive relationship between trade openness and economic growth, and documented that the evidence from cross country growth regression is not weak and therefore, outward-oriented policies could not be rejected. More to the point, Fiestas (2005) have argued that despite methodological issues, there is no evidence that trade liberalization is harmful for economic growth. Tahir and Norulazidah (2013), Tahir and Khan (2014) and Tahir (2013) reported a positive relationship between trade openness and economic growth for both developed and developing countries. Again, Tahir and Norulazidah (2014) reviewed both the theoretical and empirical literature on trade openness and economic growth and concluded that indeed there is a positive relationship between trade openness and economic growth.

With reference to the developing countries, Sachs and Warner (1995) found that open developing economies grew faster than the closed developing economies over the years. It follows, that integration to the world economy is in the interest of the developing countries from growth perspective. Dollar (1992) proposed two indices for measuring trade liberalization and found that there is a positive relationship between trade liberalization and economic performance. The study conducted by Yanikkaya (2003) has questioned the conventional wisdom regarding the relationship 
between trade restrictions and economic growth in the context of the developing countries. Ackah (2008) has argued that trade liberalization influences economic growth positively in relatively richer economies. On the contrary, Dowrick and Golley (2004) commented that most of the benefits of trade liberalization have occurred in the developed countries post 1980s.

Dava (2012) has argued that the debate on the relationship between trade openness and economic growth has not yet been settled. In the same way, Ulasan (2012) commented that the debate on tradegrowth relationship is controversial and the available literature has not provided convincing and robust evidence. Further, it is argued that theory does not provide a decisive answer about the relationship between trade openness and economic growth. Also, Stensnes (2006) has rightly asserted that a robust relationship between trade openness and economic growth has not been established yet, and the relationship between trade openness and growth should be determined empirically because of ambiguities in the theoretical models.

There are different factors explaining why researchers have not been able to provide an explicit answer to the question of whether trade openness really matters for achieving a higher economic growth. Firstly, the quality of data may be poor especially in the context of low-income developing countries. Secondly, sample heterogeneity is also a potential factor behind mixed empirical evidence. The presence of both the developed and developing countries in the same sample might be misleading, and hence generalization based on such analysis might be doubtful. This might imply that such an exercise might not uncover the true relationship. Thirdly, a clear cut mechanism by which trade openness influences economic growth is ambiguous. Therefore, the only option researchers do have is to deal with the trade - growth relationship empirically.

\section{Some Observations on Trade Openness and Economic Growth}

International trade has increased especially among the developing countries over the last few decades. According to Table 1, percentage increase of 28 percent in average trade openness can be seen for the developing countries during 1990 to 2009. Arguably, this increase in trade openness has also contributed significantly to economic growth. Similarly, the average per capita GDP in purchasing power parity has also increased for the developing countries from 3406.31 in 1990 to 5116.81 in 2009, showing an increase of almost of 50.21 percent. In addition, a scatter diagram in Figure 1 depicts the growth of real per capita GDP during 1990 to 2009 of the entire sample.

In Figure 1, the actual openness is plotted on horizontal axis while the growth of per capita GDP is measured on vertical axis. The scatter diagram shows a positive relationship between per capita GDP growth and trade openness. Simple correlation between the growth of per capita GDP and the degree of trade openness is 0.21 . The observed positive relationship is not very strong and it could be due to sample size and its representativeness. There are different groups of developing countries and hence their degree of trade openness may be significantly different. 
Figure 1: The Relationship between Per Capita GDP and Trade Openness

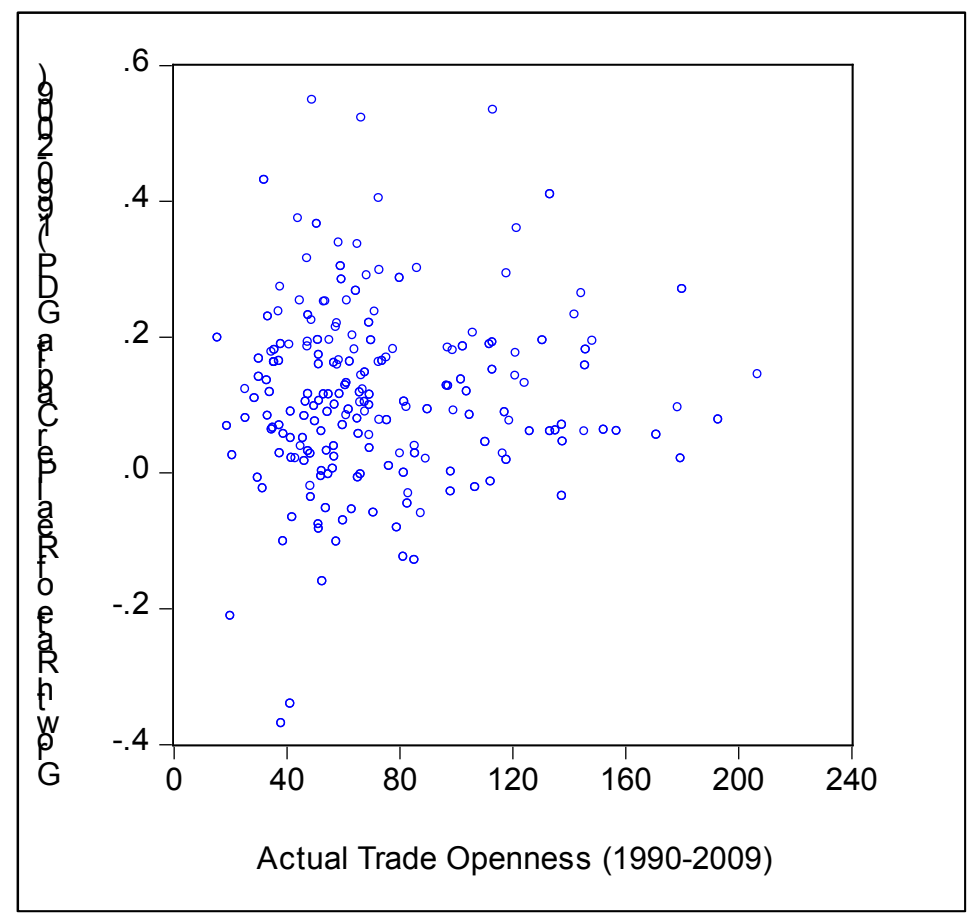

Source: Heston, Summers \& Aten, 2011 [Penn World Tables, Version: 7]

As mentioned in Table 1, there are significant variations in the degree of trade openness of uppermiddle income, lower-middle income and low income countries. Owing to these apparent differences in trade openness, we could not see a strong relationship between trade openness and economic growth as shown in Figure 1. The sub division of the sample (as shown in Table 1) shows that the openness degree is increased from 64.39 to 77.74 for upper middle economies, from 65.98 to 84.67 for lower-middle-income economies, and from 41.67 to 61.85 for low-income economies from the period 1990 to 2009. Table 1, also reports changes in per capita GDP for different sets of the developing countries.

Table 1: The Relationship between Trade Openness and Per Capita GDP (1990-2009)

\begin{tabular}{|c|c|c|c|c|c|c|}
\hline Countries & $\begin{array}{l}\text { Trade } \\
\text { openness } \\
(1990)\end{array}$ & $\begin{array}{l}\text { Per capita } \\
\text { GDP } \\
(1990)\end{array}$ & $\begin{array}{l}\text { Trade } \\
\text { openness } \\
(\mathbf{2 0 0 9 )}\end{array}$ & $\begin{array}{l}\text { Per capita } \\
\text { GDP } \\
(\mathbf{2 0 0 9 )}\end{array}$ & $\begin{array}{l}\text { Percentage } \\
\text { change in } \\
\text { openness }\end{array}$ & $\begin{array}{l}\text { Percentage } \\
\text { change in per } \\
\text { capita GDP }\end{array}$ \\
\hline Whole sample (67) & 60.28 & 3406.31 & 77.21 & 5116.81 & $28.08 \%$ & $50.21 \%$ \\
\hline $\begin{array}{l}\text { Upper-middle- } \\
\text { income }(26)\end{array}$ & 64.39 & 6014.33 & 77.74 & 9342.31 & $20.73 \%$ & $55.33 \%$ \\
\hline $\begin{array}{l}\text { Lower- middle } \\
\text { income }(27)\end{array}$ & 65.98 & 2257.14 & 84.67 & 3177.75 & $28.32 \%$ & $40.78 \%$ \\
\hline Low income (14) & 41.68 & 779.06 & 61.85 & 1009.07 & $48.40 \%$ & $29.52 \%$ \\
\hline
\end{tabular}

Source: Heston, Summers \& Aten, 2011 [Penn World Tables, Version: 7]

Table 1, shows that among the developing countries, low-income economies are still far behind in terms of openness compared to upper-middle and lower-middle-income economies. The degree of trade openness is 84.67 for lower-middle-income countries, 77.74 percent for upper-middle-income 
countries, and only 61.85 for the low-income countries in 2009. The possible reason for the above observation might be that the low-income countries are far behind in terms of per capita GDP.

Further, Table 1 shows changes in per capita GDP for different sets of countries included in the sample. There is a close relationship between the changes in openness and changes in per capita GDP. The countries with low openness degree are also having low level of per capita GDP. The uppermiddle-income and lower-middle-income countries are much more open than low-income countries, and hence their per capita is also high compared to low-income countries. The low-income countries have achieved an increase of 29.52 percent in GDP per capita during the period from 1990-2009. Data shows that the degree of trade openness has increased by 48.40 percent for the low-income countries, but further increase is required as the openness in 2009 is 61.85 , which is still far behind as compared to upper-middle-income and lower-middle-income countries.

\section{Model, Methodology, Sample, and Data Sources}

\subsection{The Model}

Trade theories and growth theories support the hypothesis that trade openness enhances economic growth. This hypothesis is tested with the help of standard panel econometric techniques in order to control for the unobserved factors. However, economic growth is indeed a complex process and hence cannot be explained by a single determinant of economic growth such as trade openness or investment. Economic growth can be influenced by various determinants. Both domestic investment and labour force determine the productive capacity of an economy, and are considered to be the key determinants of growth. Human capital or simply education also influences economic growth by improving the productive efficiency.

Further, macroeconomic environment also matters for the smooth functioning of an economy. Frequent fluctuations in macroeconomic variables adversely affect economic activities. Similarly, uncertainty in policies shatters confidence of investors, and hence growth rate declines. In addition, sound institutional system is also equally important for achieving higher economic growth like all other determinants. Sound institutions affectively coordinate among different sectors of the economy and further provide a platform to all stakeholders to play their part in the national development process. However, institutions are indeed difficult to measure. Therefore, we capture the overall impact of institutional factors through democratic system with the assumption that only democratic government can enhance the quality of institutions. In other words, the presence of democratic government is an indication of good institutions. The following model is specified for analysis:

$$
\begin{aligned}
\operatorname{grgdpch}_{i t} & =b_{0}+b_{1} \operatorname{lninv}_{i t}+b_{2} \text { lnopenk }_{i t}+b_{3} \text { glabf }_{i t}+b_{4} \text { lned }_{i t} \\
& +b_{5} \text { lnsdinfl }_{i t}+b_{6} \text { dem }_{i t}+U_{i t}
\end{aligned}
$$

The subscript $(i)$ represents cross sectional dimension of the data and $(t)$ stands for the time dimension of the data. The term $\left(\operatorname{grgdpch}_{i t}\right)$ stands for the dependent variable and measures growth of real per capita GDP in purchasing power parity. $\left(\operatorname{lnin} v_{i t}\right)$ denotes domestic capital formation and is used as a proxy for investment. Trade openness is denoted by (nopenk $k_{i t}$ ) and is calculated by dividing the sum of exports plus imports on GDP $(X+M / G D P)$. All quantities are in real terms. The term $\left(g l a b f_{i t}\right)$ stands for the growth of labour force, which is calculated as the growth rate of population ageing between 15 to 64 years. For education (lned $u_{i t}$ ), gross enrolment ratio at secondary level is used regardless of age group, and ( $\left.\operatorname{lns} \operatorname{din} f l_{i t}\right)$ refers to inflation volatility which is 
measured as the standard deviation of inflation, while $\operatorname{dem}_{i t}$ stands for democracy, which measures institutional aspect and it has been approximated by an index which ranges from +10 (Democratic) to -10 (Autocratic).

\subsection{Sample and Data Sources}

Keeping in mind the objective of the paper, a list of countries based on per capita GDP has been collected from the World Bank. The World Bank has categorized countries in to different groups based on per capita GDP. Based on data availability, only 67 developing countries are chosen for the sample, which consists of 14 lower-incomes, 27 lower-middle-income and 26 upper-middle-income countries (see appendix for the list of countries). The upper -middle- income countries are those where per capita GDP is ranging between 3976 to 12275 dollars. The countries where per capita GDP is greater than 1006 dollars and less than 3975 dollars, are named as lower-middle-income countries. The third group of countries among the developing countries are named as low-income countries, where per capita GDP is only 1005 dollars or less. Data ranging from 1990 to 2009, are converted to 5 year averages in order to avoid the short run fluctuations that could affect the relationship between the independent variables and the dependent variable (Harrison, 1995). Data on GDP per capita, trade openness and population are taken from Penn World Tables (Heston et al., 2011). Data on gross fixed capital formation as a ratio of GDP, inflation rate and labour force are obtained from World Bank development indicators (World Bank, 1990-2009). Educational and democracy data are obtained from CANA database (Castellacci \& Natera, 2011).

\subsection{The Endogeneity Problem}

The conventional measure of trade openness (exports plus imports as a ratio of GDP) which is also used in this paper is endogenous in the growth equation (1). It is because of the fact that foreign trade pattern of a country can also be affected by its size regardless of its trade policy. Researches have also highlighted the endogeneity issues associated with the measure of trade openness (Frankel \& Romer; 1999, Winters; 2004).

We assume that size of a country can influence its foreign trade pattern. However, the point we want to make here is that the relationship between size of a country and its foreign trade also depends on the productive capacity of domestic economy. To put it differently, a country with even a high population may trade more if it is incapable to produce enough to meet the demands of its domestic consumers and producers. It may trade less, if it produces sufficient to fulfil the domestic demands of its consumers and producers. This implies that the productive capacity of an economy plays a significant role in determining its pattern of foreign trade. It is, therefore, important to adjust the crude trade openness of each country for its size in order to eliminate the impact of size of the country on its degree of trade openness. To do this, 20 years' data on trade openness is regressed on 20 years' data on a total population of included countries in the sample. The fitted values are collected and converted to 5 years averages. These averages are in turn used as an instrument for trade openness in the growth regression. The simple correlation coefficient between the actual trade openness and the fitted values is (0.93), which shows the strength of the instrument. The actual trade openness is plotted against the instrumented trade openness in Figure 2 as bellow: 
Figure 2: The Relationship between the Actual Trade Openness and Instrumented Trade Openness

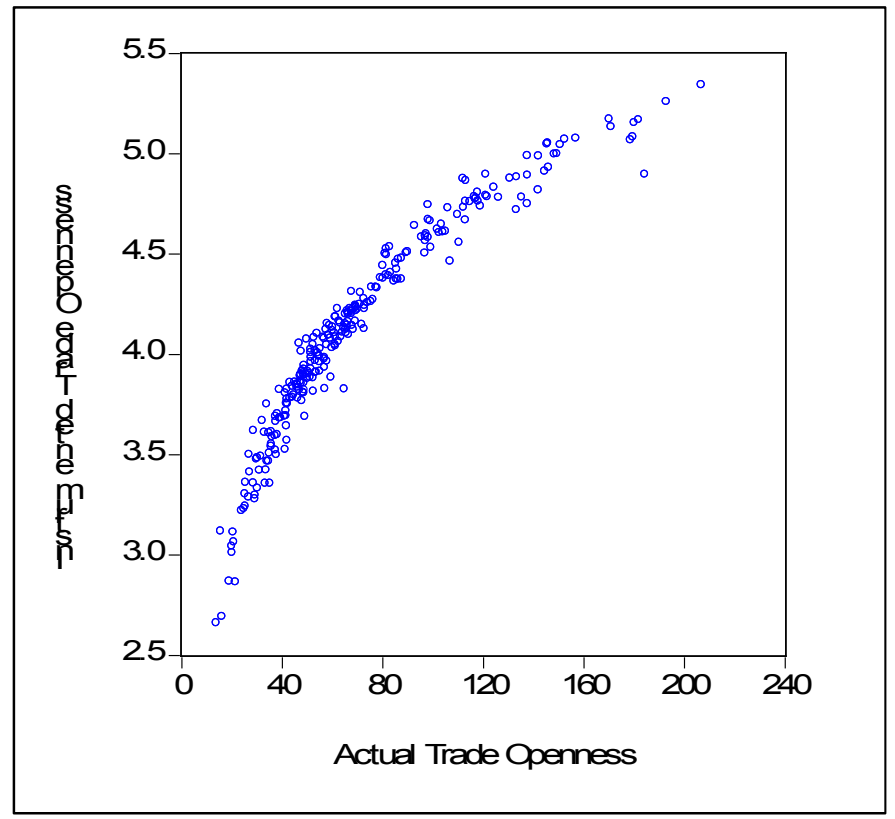

In Figure 2, the actual trade openness and instrumented trade openness are plotted on horizontal axis and vertical axis respectively. The Figure displays a strong positive relationship between the actual trade openness and instrumented trade openness. Both quantities are moving in the same direction. Most of the data points are overlapping, showing the validity of the instrument.

Table 2: Main Growth Regression Results

\begin{tabular}{|c|c|c|c|c|}
\hline \multirow[t]{2}{*}{ Variables } & \multicolumn{2}{|c|}{$\begin{array}{l}\text { Whole Sample (67) } \\
\text { Upper-middle- } \\
\text { income+Lower-middle } \\
\text { income+Low income } \\
\text { countries }\end{array}$} & \multicolumn{2}{|c|}{$\begin{array}{l}\text { Sub Sample (41) } \\
\text { Low-income+Lower-middle- } \\
\text { income countries }\end{array}$} \\
\hline & Fixed Effects & Fixed Effects & Fixed Effects & Fixed Effects \\
\hline Constant & -0.91 & -1.07 & -1.10 & -1.49 \\
\hline 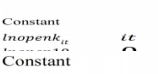 & $0.07 *$ & & $0.13^{* * *}$ & \\
\hline 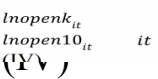 & & $0.10 * * *$ & & $0.22 * * *$ \\
\hline $\begin{array}{l}\text { Inopenii } \\
\text { IV) } \\
\text { Intnvit it it }\end{array}$ & $0.12 * * *$ & $0.12 * * *$ & $0.07 * *$ & $0.08 * *$ \\
\hline 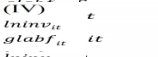 & $0.71 * * *$ & $0.67 * * *$ & $0.89 * * *$ & $0.86^{* * *}$ \\
\hline 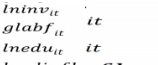 & $0.09 * * *$ & $0.09 * * *$ & $0.10 * * *$ & $0.12 * * *$ \\
\hline 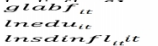 & $-0.04 * * *$ & $-0.04 * * *$ & $-0.05 * * *$ & $-0.05 * * *$ \\
\hline $\begin{array}{l}\text { inedinfl }_{i t} \\
\text { insd } \\
\text { demit }^{i t}\end{array}$ & $0.003 * * *$ & $0.003 * * *$ & 0.003 & 0.004 \\
\hline $\begin{array}{l}\text { Statistical } \\
\text { criteria }\end{array}$ & $\begin{array}{l}\mathrm{R}^{2}=0.68 \\
\text { Adj- } \mathrm{R}^{2}=0.50 \\
\mathrm{SER}=0.09 \\
\mathrm{~F}=3.76\end{array}$ & $\begin{array}{l}\mathrm{R}^{2}=0.69 \\
\text { Adj- } \mathrm{R}^{2}= \\
0.51 ; \mathrm{SER}= \\
0.09 \\
\mathrm{~F}=3.79\end{array}$ & $\begin{array}{l}R^{2}=0.69 \\
\text { Adj- } R^{2}=0.50 \\
S E R=0.09 \\
F=3.56\end{array}$ & $\begin{array}{l}\mathrm{R}^{2}=0.70 \\
\text { Adj- } \mathrm{R}^{2}=0.50 \\
\mathrm{SER}=0.09 \\
\mathrm{~F}=3.61\end{array}$ \\
\hline
\end{tabular}


Note: The dependent variable is the growth of real per capita GDP. $(* * *),(* *)$ and $(*)$ stands for $1 \%, 5 \%$ and $10 \%$ level of significance.

In the last section, an instrument for trade openness is constructed in order to address the likely endogeneity of trade openness. Before estimating the models, F-test is conducted to see whether, indeed, panel data techniques are necessary or not. Also, the Hausman test is performed to choose between the fixed effects and random effects model. The F-test displayed the presence of fixed effects, while the Hausman specification test (1978) preferred the fixed effects model over random effects model. Therefore, pooled least square estimation and random effects estimation are not appropriate. The heteroscedasticity problem is corrected by estimating models with White (1980) robust estimator. Two regression models, one with actual trade openness, and one with instrumented trade openness are estimated for the entire sample of 67 developing countries as well as for the subsample of 41 developing countries. Regression results are displayed in Table 2.

\section{Results and Discussion}

The results based on fixed effects estimation seems to be consistent with economic theory and also with past empirical research. The actual trade openness is significantly different from zero at 10 percent level for the whole sample of 67 developing countries and at 1 percent level for 41 lowincome and lower-middle-income developing countries. Also, the instrumented trade openness is statistically significant at 1 percent level for both samples. This might suggest that open trade policies are relevant for accelerating economic growth in the developing countries. It is, therefore, in the interest of the developing countries to speed up the process of trade liberalization in order to grow faster and match with the economic growth of richer countries.

The results suggest that the developing countries in general should not worry about the weak arguments favouring protectionism. It has been observed over the years that the developing countries, particularly, the less developing countries are reluctant to open up their markets in to the global economy. However, survival without integrating into the global network is almost impossible in today's complex world. Therefore, the developing countries are suggested to specialize according to the theory of comparative advantage in order to achieve both production gains and consumption gains. The production and consumption gains over the years would contribute to the growth process of the developing countries remarkably.

The domestic investment and labour force, which are considered as drivers of economic growth in both theoretical and empirical literature, have reported positive coefficients and are statistically significant at standard levels. The developing countries, therefore, are suggested to pay favourable attention to the basic determinants of economic growth such as investment and labour force in order to improve their growth rates. The surplus and idle labour force, especially in the less-developing countries could be tackled through encouraging additional investment in the domestic economy.

Human capital, which is approximated by gross enrolment rates at secondary level, bears a positive sign in the estimated regression models and it is also statistically significant. The results suggest that the developing countries need to invest in human capital. For instance, educating more people will boost the growth process, especially in the developing countries. It is an undeniable fact that educated labour force can play its part in the process of production more efficiently compared to the ordinary labour force. 
Inflation volatility is also highly significant at 1 percent level and carries a negative coefficient, confirming that frequent fluctuations in prices are detrimental to economic growth. Likewise, the issue of uncertainty in policies is harmful to economic growth. The policies, especially in developing countries, are unstable and unpredictable. This suggests that macroeconomic policies should be properly managed and executed in order to eliminate its harmful effects on economic growth.

Further, it is found that the impact of democracy, which is being used as a proxy for institutional factor, is not only positive, but also, statistically significant. This implies that the developing countries should reject inefficient forms of governments such as dictatorship and move towards democratic regimes. The impact of democracy on economic growth however, is positive; although it is also statistically insignificant for low-income and lower-middle-income countries. The poor nature of democratic governments and its involvement in corrupt practices could explain the insignificant impact of democracy on economic growth in the context of low-income and lower-middle-income economies.

Adjusted R-squared for the whole sample of 67 developing countries is $0.50,0.51$ for the models with actual trade openness and instrumented trade openness respectively, indicating that 50 percent variation in the growth of per capita GDP is explained by the fitted models. For the sub-sample sample of 41 lower-middle and low-income countries, the fitted models can explain 50 percent variation in growth process. F-statistic is also statistically significant in all cases at 1 percent level, indicating that the estimated models fit the data well.

\section{Concluding Remarks and Policy Recommendations}

This paper has examined the impact of trade openness on economic growth for the developing countries. First, empirical analyses are carried out for the whole sample of 67 developing countries, consisting of upper-middle-income, lower-middle-income, and low-income developing countries. Second, the trade-growth relationship is also tested for low-income and lower-middle-income developing countries together. However, due to small sample size, regressions models are not estimated separately for lower middle income and low income developing countries. Not running separate regressions for different groups of countries is a limitation of the paper, especially given that the behaviour of the data does not appear to be similar (i.e., in lower-middle income countries, there is a large change in growth corresponding to a small change in openness, whereas in low income countries there is only a small change in growth corresponding to a large change in openness; see Table 1). Panel econometric tools are applied using data from 1990-2009 for the empirical analysis.

The results show that openness to international trade matters for achieving higher economic growth in the developing countries. Furthermore, it is found that the positive relationship between trade openness and economic growth is applicable to the lower-middle-income and low-income developing countries. However, given the above stated limitation, the latter is not a clear finding. In addition, a positive relationship is observed between domestic investment, labour force, education, democracy, and economic growth. A negative relationship is found between inflation volatility and economic growth for both samples.

The developing countries in general are suggested to speed up the process of trade liberalization in order to grow faster in the long run. Also the lower middle income countries and low income countries should also take appropriate steps in order to ensure greater participation in global trade. However, it should also be noted that the suggested recommendations are not very conclusive due to 
the fact that separate regression models are not estimated owing to small sample size. Similarly, a favourable attention could be made by the developing countries in general to the basic determinants of economic growth if they want to improve their economic conditions. Further, efforts are required on the part of policy makers to ensure macroeconomic stability. Lastly, an efficient democratic government will also contribute to the growth process of the developing countries.

\section{References}

Ackah, C. (2008). For richer or poorer: Trade policy and growth in developing countries. Paper presented at UNECA Ad-hoc Expert Group Meeting on Macroeconomic Policy Productive Capacity and Growth in Africa, Addis Ababa.

Bajona, C., Gibson, M. J., Kehoe, T. J., \& Ruhl, K. J. (2010). Trade liberalization, growth, and productivity. Paper presented at New directions in international trade theory. University of Nottingham.

Bhagwati, J., \& Srinivasan, N. (2001). Outward-orientation and development: Are revisionists right? (Discussion Paper No. 806). Economic Growth Center.

Castellacci, F., \& Natera, J. M. (2011). A new panel dataset for cross-country analyses of national systems, growth and development (CANA) (MPRA Paper No. 28736). Munich Personal RePEc Archive

Carbaugh, J. R. (2005). International economics. United States: Thomson South-Westeron.

Dava, E. (2012, September). Trade liberalization and economic growth in the SADC: A difference-indifference alnalysis. Paper presented at Moçambique: Acumulação Transformação Contexto de Crise Internacional

Dobre, C. (2008). The relationship between openness to trade and economic growth. Analele Stiintifice Ale Universitătii Alexandru ioan Cuza Din IASI, 237-247

Dollar, D. (1992). Outward-oriented economies really do grow more rapidly: Evidence from 95 LDCs. Economic Development and Cultural Change, 40(3), 523-544.

Dollar, D., \& Kraay, A. ( 2002). Trade, growth, and poverty. Economic Journal 114 (493), 22-49.

Dowrick, S., \& Golley, J. (2004). Trade openness and growth: Who benefits? Oxford Review of Economic Policy, 20(1), 38-56.

Edwards, S. (1998). Openness, productivity and growth: What do we really know? The Economic Journal, 108, 383-398.

Fiestas, I. (2005). The effects of trade liberalization on growth, poverty and inequality. CILAE Nota técnica NT/04/05.

Frankel, A. J., \& Romer, D. (1999). Does trade cause growth? The American Economic Review, 89(3), 379-399.

Grossman, M., \& Helpman, E. (1994). Endogenous innovation in the theory of growth. The Journal of Economic Perspectives, 8(1), 23-44.

Harrison, A. (1995). Openness and growth: A time series, cross-country analysis for developing countries (NBER Working Paper No. 5221). Cambridge, MA: National Bureau of Economic Research

Hausman, J. (1978). Specification tests in econometrics. Econometrica, 46 (6), 1251-1271.

Heston, A., Summers, R., \& Aten, B. (2011). Penn World Table Version 7.0. Center for International Comparisons of Production, Income and Prices at the University of Pennsylvania. Retrieved from http://www.rug.nl/research/ggdc/data/pwt/pwt-7.0

Lin, S. (2000). Foreign trade and China's economic development: A time-series analysis. Journal of Economic Development, 25(1), 145-153. 
Lopez, A. (2005). Trade and growth: Reconciling the macroeconomic and microeconomic evidence . Journal of Economic Surveys, 19(4), 623-648.

Panagariya, A. (2004). Miracles and debacles: In defence of trade openness. World Economy, 27(8).

Rodríguez, F. (2007). Openness and growth: What have we learned? (DESA Working Paper No. 51).

Rodrik, D., \& Rodriguez, F. (2000). Trade policy and economic growth: A skeptics guide to the crossnational evidence (NBER Working Paper No. 7081). Cambridge, MA: National Bureau of Economic Research

Ricardo, D. (1817). The principles of political economy and taxation. London: Everyman, 1992.

Smith, A. (1976). An inquiry into the nature and causes of the wealth of nations. Oxford: Clarendon Press.

Sachs, D. J., \& Warner, A. (1995). Economic reforms and the process of global integration. Brooking Papers on Economic Activity, 1995(1), 1-118.

Stensnes, K. (2006). Trade openness and economic growth do institutions matter? (Paper No. 702). Norwegian Institute of International Affairs

Tahir, M. (2013). Import openness and economic growth: Cross sectional evidence from OECD. International Journal of Economics and Research, 4(1), 1-7.

Tahir, M., \& Khan, I. (2014). Trade openness and economic growth in the Asian region. Journal of Chinese Economic and Foreign Trade Studies, 7(3), 136-152.

Tahir, M., \& Norulazidah, H. (2014). Trade openness and economic growth: A review of the literature. Asian Social Science, 10(9), p137-143.

Tahir, M., \& Norulazidah, H. (2013). The relationship between trade and income: The case of developed countries. International Research Journal of Finance and Economics, (111), 138-145.

Thirlwall, P. (2000). Trade liberalisation and economic growth: Theory and evidence (Economic research paper No. 63). African Development Bank.

Ulaşan, B. (2012). Openness to international trade and economic growth: A cross-country empirical investigation. Economics, 1-58. http://www.economics-ejournal.org/economics/discussionpapers /2012-25.

Wacziarg, R., \& Welch, H. K. (2003). Trade liberalization and economic growth: New evidence (NBER Working Paper No. 10152). Cambridge, MA: National Bureau of Economic Research

Warner, A. (2003). Once more in to the breach: Economic growth and integration (Working Paper No. 34). Center for Global Development.

White, H. (1980). A heterokedasticity-consistent covariance matrix estimator and a direct test for heterokedasticity. Econometica, 48(2), 817-38.

Winters, A. (2004). Trade liberalization and economic performance: An overview. The Economic Journal, 114, 4-21.

World Bank (1990-2009). World development indicators. Retrieved from http://data.worldbank.org/ data-catalog/world-development-indicators

Yanikkaya, H. (2003). Trade openness and economic growth: A cross-country empirical investigation. Journal of Development Economics, 72, 57-89. doi:10.1016/S0304-3878(03)00068-3. 


\section{Appendices}

Appendix 1: List of the Total Sample (67 Developing Countries)

\begin{tabular}{llll}
\hline Albania & Guatemala & Paraguay & Benin \\
Algeria & Guyana & Peru & Chad \\
Angola & Honduras & Philippines & Ethiopia \\
Bolivia & India & Romania & Guinea \\
Botswana & Indonesia & Russia & Kenya \\
Brazil & Iran & Senegal & Madagascar \\
Bulgaria & Lebanon & South Africa & Malawi \\
Cameroon & Lesotho & Sri Lanka & Mozambique \\
Chile & Malaysia & Sudan & Nepal \\
China & Mauritania & Swaziland & Rwanda \\
Colombia & Mauritius & Thailand & Sierra Leone \\
Cote d Ivoire & Mexico & Tunisia & Tanzania \\
Dominican Republic & Mongolia & Turkey & Uganda \\
Egypt & Morocco & Uruguay & \\
El Salvador & Namibia & Uzbekistan & \\
Fiji & Nicaragua & Venezuela & \\
Gabon & Pakistan & Zambia & \\
Ghana & Panama & Bangladesh & \\
\hline
\end{tabular}

Appendix 2: Lower-Middle-Income and Low-Income Developing Countries (41 Countries)

\begin{tabular}{llll}
\hline Angola & India & Sri Lanka & Madagascar \\
Bolivia & Indonesia & Sudan & Malawi \\
Cameroon & Lesotho & Swaziland & Mozambique \\
Cote d'Ivoire & Mauritania & Uzbekistan & Nepal \\
Egypt & Mongolia & Zambia & Rwanda \\
El Salvador & Morocco & Bangladesh & Sierra Leone \\
Fiji & Nicaragua & Benin & Tanzania \\
Ghana & Pakistan & Chad & Uganda \\
Guatemala & Paraguay & Ethiopia & \\
Guyana & Philippines & Guinea & \\
Honduras & Senegal & Kenya &
\end{tabular}

